\title{
TESTS ON FULL-SCALE AND STATIC ANALYSIS MODELS OF THE WOOD-FRAMED BUILDING STUCTURE HORIZONTALY LOADED
}

\author{
Jaroslaw MALESZA ${ }^{\mathrm{a}}$, Czeslaw MIEDZIALOWSKI ${ }^{\mathrm{a}}$, Leonas USTINOVICHIUS ${ }^{\mathrm{b}}$ \\ ${ }^{a}$ Bialystok University of Technology, ul. Wiejska 45a, 15-351 Bialystok, Poland \\ ${ }^{b}$ Vilnius Gediminas Technical University, Sauletekio al. 11, LT-10223 Vilnius, Lithuania
}

Received 19 Dec 2016; accepted 10 Mar 2017

\begin{abstract}
This paper focuses on development of the high energy saving timber building and ecological technology protecting environment in civil engineering. Wood framed with sheathing, large panel structures became more popular building constructions in Poland last decade. Experimental tests and numerical analysis of panels and complete woodframed building have been taken into account. Typical two-story residential building was selected for test. Test of threedimensional (3D) whole building was conducted on the base of experimental investigations results of large panel similar to those used in building structure. Also adequate tests of materials and connections were accompanying of the whole structure investigations. Obtained results were adopted in numerical models elaborated for wall and floor panels and in 3D model of whole building. Load -displacements characteristics were acquired from tests and numerical models. The displacements computed from 3D numerical model were $10-20 \%$ higher than from experiment. Experimentally obtained lower displacements than those from analytical analysis are resulted from higher stiffness of wall system due to diaphragms interconnections, their common interaction and three-dimensional character of building structure. Presented research analyzed method of computation of internal forces in building as well in the range of engineering methods in the form of rigid beam scheme up to the advanced methods using 3D spatial model adopting FEM.
\end{abstract}

Keywords: paneled building structure, wood-framed building, numeric model, full scale test.

\section{Introduction}

In the world literature there are minor number of experimental tests on full-scale the wood-framed buildings (Van de Lindt et al. 2012) because the cost associated with tests and required for this kind of investigations large facilities. Also equipment can be damaged when test is developed to the point of collapse. The light wood-framed garage wall was tested under dynamic load to the failure stage and results of numeric model simulated behavior of structure along the all path of loading. In Doudak et al. (2012) also Wang and Eamon (2013), few low-rise woodframed buildings structures were tested in full size to discover how the whole structure system react to excessive wind loads. Midrise wood-frame buildings were constructed on the base of wood-frame shear walls system and eight walls $2440 \times 2440 \mathrm{~mm}$ diaphragms were tested in Hong et al. (2012) under monotonic and cyclic load. Failure modes, influence of vertical load on stiffness and improvements in shear stiffness are examined in the paper. Paper by Ni et al. (2012) presents behavior of natural scale portal frame walls in wood-frame buildings. Results obtained from finite-element model compared to the tests results indicate influence of wall height, sheathing placements and nailing pattern on lateral load capacity and stiffness. Nail as the steel beam elements in the algorithm of the finite-element model in a wood shear wall is analyzed in paper by Li et al. (2012). Damage model parameter for wood shear walls is proposed in paper of Liang et al. (2011). The research indicates that displacements are not the only indicator for seismic performance of wood building and proposed damage index criterion leads to realistic evaluation. Parameters influencing shear strength of the shear walls: the bearing capacity, internal stressing, geometric and material properties are presented in analysis method proposed in paper of Kassem and Elsheikh (2010). Tests programs demonstrating how the mid-rise wood-frame buildings respond to a dynamic loading and results of test of full-scale buildings are included in papers of Van de Lindt et al. (2010a, 2010b), Pei et al. (2013), Van de Lindt et al. (2013). Building performance and global drift of structure under dynamic load was evaluated on the damage inspections of walls. Direct displacement design procedure for midrise wood- 
frame structures and set of factors influencing specified performance level factors are included in paper of Wang et al. (2010). Degradation in racking stiffness of light frame wood construction of the full-scale L-shape single story building after continuously repeated cyclic lateral loads were not observed according to experimental study in Songlai et al. (2010), while loading with intervals caused degradation in lateral stiffness. Restrictions in drift for lateral load allow to calculate the racking capacity of gypsum sheathings. Papers (Pang et al. 2010; Pang, Shirazi 2013) present a simplified direct displacement design procedure which was used to design the shear walls for mid-rise wood-frame buildings. Building was tested awaiting failure limits, safety of structure life and collapse prevention. The tests were conducted on the woodframed wall dimension of $2.40 \mathrm{~m}$ by $2.40 \mathrm{~m}$ segments according to paper by Winkel and Smith (2010).

Wall diaphragms were constructed with the oriented strand-board sheathing nailed to timber framing. Responses of structure to in-plane and out-of plane were find-out in adequate combinations. Obtained within the tests results indicated that some in-plane components of loadings reduced strength capacity of diaphragms comparative to existing of only one in plane force component. The theory of a beam on a nonlinear foundation in the solid element modeling the three-dimensional nonlinear finite-element model of single nail connection was developed (Hong, Barrett 2010). In order to have the connection model account for crushing behavior of wood during the nail embedment, a procedure was studied to implement the theory of a beam on a nonlinear foundation in the solid element modeling. The model predictions indicated adequate agreement with the load-slip characteristic and the actual deformed shapes of the connections. The main objective of experimental study of a full-scale, twostory wood-frame building presented in Filiatrault et al. (2010) was to determine the dynamic characteristics and the seismic performance of building. The test results showed that the gypsum board to the interior surfaces of wood sheathed walls substantially improved the seismic response of structure. Log walls tests presented in Graham et al. (2010) withstood large in-plane displacements without significant load reduction using lateral bracing typical of that used for light-frame wall testing. The .main objective of paper by Van de Lindt et al. (2010a) was verification of the accuracy of the predictions from the model, which incorporates shear deformations of shear walls as well as floor displacements caused by the out-ofplane rotations of the floor and ceiling diaphragms. Good agreement was found between the numerical predictions and test results for the four different construction phases.

A significant number of the residential building in Poland and in the Countries of Central Europe is constructed in the wood framed with sheathing technology. North-eastern part of Poland, Lithuania and Scandinavia are covered with the biggest forest complexes still existing in Europe. Therefore this method of housing con- struction implemented with new technology of manufacturing creates progressive future for building industry. Comparing to the former traditional in Poland in the past construction technology of the solid wood log walls, the wood-framed buildings use low volume of lumber. Solid wood is used in construction of the wall, floors and roof diaphragms (studs, floor joints, roof rafters and girders). Lateral stiffness of diaphragms is achieved applying plywood, chipboards or the other structural board of sheathing to the timber frame. Fasteners linking sheathing to the wooden frame and diaphragms interconnecting links redistribute loading in the structural elements, and they are affecting the lateral strength and displacements of buildings (Hite, Shenton 2002; Robertson, Griffiths 1981). Layer of mineral wool placed between studs and joists supplemented outside of the wall diaphragms satisfies predicted conditions of thermal and acoustic requirements. The paper presents examples of construction, selected results of experimental tests and analytical modelling and investigations of newly constructed the woodframed with sheathing buildings.

The contribution of the paper is evaluation on the base of tests on natural scale building how the reliably used analytical models of varying precision (1D, 2D, 3D) are describing static behaviour of this type building structure. In the presented document has been used author's numerical model 3D of analysis, which was earlier described in the Journal of Civil Engineering and Management (Malesza, Miedzialowski 2006). That model allows for analysis of particular structure assemblies including connections and fasteners as well as it leads to assign the mostly stressed structural elements also in the post elastic range.

\section{Wood-framed construction in Poland}

Within last decade the wood-framed buildings became widely constructed on polish building market. Polish Standard "Design of timber structures" (1995) is dealing with procedure of design, testing and construction of the wood-framed buildings and is based on EN 1995 and its Polish edition PN-EN 1995-1-1. The wood-framed buildings do not require large volume of solid wood contrary to the former construction of timber die square walls (Malesza et al. 2013). Solid wood is used in construction of the walls, floors and roof panels as the studs, upper and bottom plates, floor joists, roof rafters and girders. Designed lateral stiffness of the vertical and horizontal diaphragms is achieved applying plywood, chipboards or the other structural wood derivative boards of sheathing fixed to the wooden frame. Fasteners connecting wooden frame and sheathing as well as the panel interconnecting links create important role in whole structure. Layer of mineral wool placed between frame and additionally added outside, satisfies predicted conditions of thermal and acoustic requirements. Implementation of the woodframed buildings structures in Poland has been involving many problems especially in respect of three dimensional 
a)

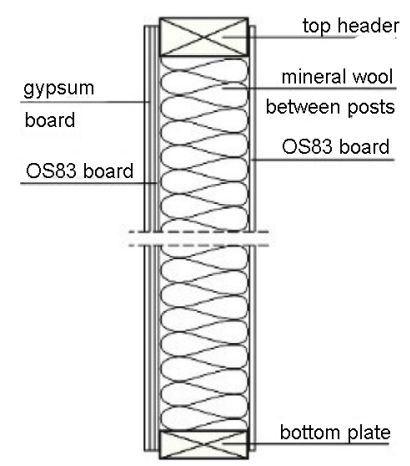

b)

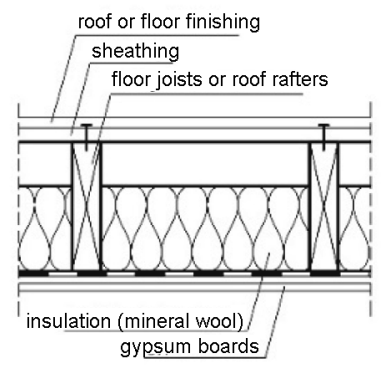

Fig. 1. Typical cross-section of the wood-framed structures and building under construction: a) wall diaphragms, b) floor and roof panel

building stiffness and moisture-thermal requirements. Typical cross-sections of the wall and floor or roof diaphragms are presented in Figure 1.

Advanced research works are conducted abroad (Tissel 1993; Tissel, Elliott 1999). These works are concentrated on improving the building structure and introduction of analytical models predicting the structure static and dynamic behaviour (Kasal, Leichti 1994; Schmidt, Moody 1989).

The wood-framed with sheathing buildings constitute timber framing with one or both sides of the woodderivative boards. Three-dimensional structural element composed in this way shall be able to transfer the vertical and horizontal lateral and perpendicular to the plane loadings according to standard requirements and assignment of 3D wood-frame with sheathing building. Panel construction in the plant and building assembling on the site presents Figure 2.

Significant approach is required in design of $3 \mathrm{D}$ stiffness of wood-framed structure, specifically while considering stability and distribution of lateral load to the stiffening walls. EQU as well as STR load combinations in EN 1990:2002 shall include all kind of horizontal and vertical loading acting to the structure.

The main objectives of the presented manuscript are investigations of the wood-framed building under construction without interior finishes, wall diaphragms tests and board-to-timber nailed connections.

\section{Tests on the whole building structure}

Experimental tests were conducted directly on the site of construction, on real constructed building. Horizontal load was developed through hydraulic operator measuring the force level in the ties. The scheme is shown in Figure 4. Standards are averaging values of loadings, for instance wind, acting to adequate areas of building structure. However, the advanced model 3D allows to analyze local, for example, at the roof corners stressing. This problem has not been considered and developed in the paper. a)

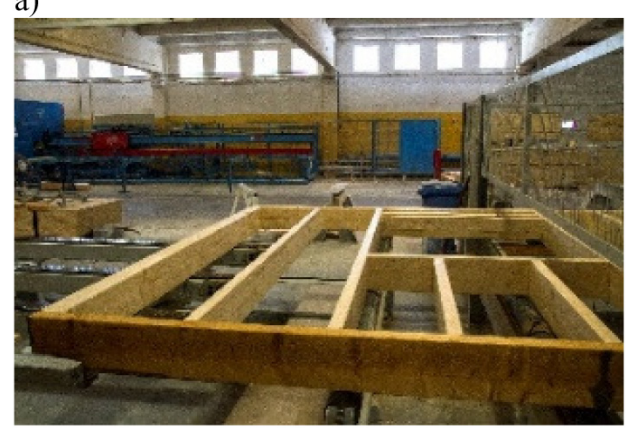

b)

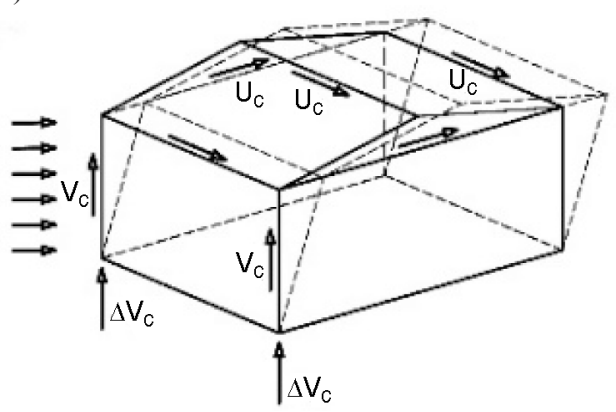

Fig. 2. a) Panel construction line in the plant, b) wood-framed structure horizontal load distribution

Different methods of lateral load distribution were used to predict the division of design wind load to the shear walls in a single story house. This method of load distribution was presented recently by Kasal et al. (2004). Participation of each wall in ensuring the stiffness of the three-dimensional structure has been addressed by Kasal and Leichti (1994) and Schmidt and Moody (1989) in the frame of testing and modeling the wood-framed buildings. Results of a series of experimental investigations on a full-scale house; sharing and redistribution of applied lateral load between the main shear walls of a light frame structure were presented in these works. These works also presents redistribution of internal forces under pseudoelastic and inelastic response conditions.

The experimental investigations and analytical modeling results of the full-scale wood-framed building structure subjected to lateral loading representing environmental wind pressure are presented in this paper.

Development of displacements and overall structural behavior under applied loading of almost completely constructed wood-framed residential building without finishes inside and cladding outside works were investigated. Displacements measured during the test for different loading levels were compared to the standard recommendations and also referred to analytically obtained results for different models describing structure.

Different wall displacements were measured during the test in order to evaluate the values and characteristics of the total building deformations. The further steps of analysis evaluate the stiffness of individual structural diaphragm, method of distribution of applied external loading on the walls also vertically loaded and analytical 
deformations of the building structure. The characteristic stiffness of the walls obtained from experimental tests were conducted on diaphragms similar to those used in building structure and they were implemented in analytical study.

The continuous beam analogy as the static scheme of floor diaphragm supported on deformable walls system, orthotropic floor slab with joists and sheathing pinned with nails on deformable walls and finally the three-dimensional shell model of the roof, floor and walls were implemented in numerical modeling. The loading applied to the structure was lower comparing to the predicted for the ultimate limit states in order to ensure the further construction and finishing foreseen for residential occupation.

Load distribution on the individual wall creating building structure and participation of each wall in ensuring the stiffness of the three-dimensional structure has been addressed only recently in Philips et al. (1993), Kasal and Leichti (1994), Schmidt and Moody (1989) in the frame of testing and modeling the wood-framed buildings.

In the frame of test, different wall displacements were measured due to estimate the values and characteristics of the total building deformations. The further steps of analysis evaluate the stiffness of individual structural diaphragm, method of distribution of applied external loading on the walls and analytical deformations of the building structure. The characteristic stiffness of the walls obtained from experimental tests conducted on diaphragms similar to those used in building structure (Malesza, Miedzialowski 1999) were implemented in analytical study. The continuous rigid-beam analogy as the static scheme of floor diaphragm supported on deformable walls system versus orthotropic floor slab mapping joists with sheathing on deformable walls were implemented in numerical modeling.

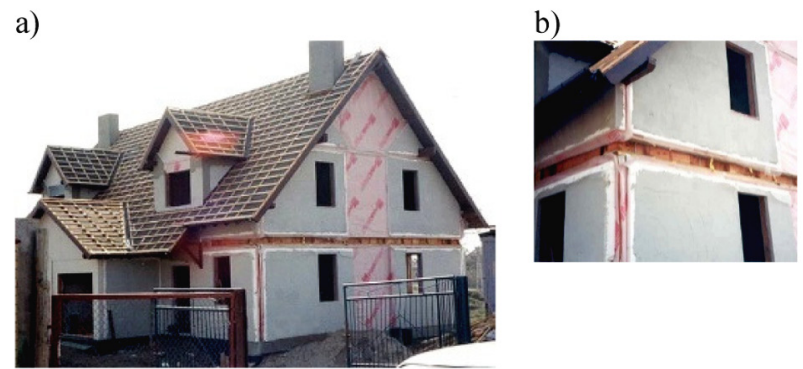

Fig. 3. Tested building: a) general view, b) details of its construction

\section{Object of study}

Analytic investigations and experimental tests were conducted in the frame of scientific cooperation with contractor realizing several wood framed buildings. Selected building was constructed to the stage without inside finishes. For experimental tests was selected building (see Fig. 3) of the wood-framed with sheathing single story with a living attic area of the large panel constructed on monolithic reinforced concrete lower structure.

The height of $2.74 \mathrm{~m}$ the first story under folded (pitched) wooden rafter roof structure inclined under 45 degree indirectly supported on wooden beams creates the building. Wall diaphragms were constructed using Polish Fir wood with studs and horizontal top and bottom plates of cross-sections $45 \times 135 \mathrm{~mm}$ spaced axially at distance of $600 \mathrm{~mm}$, with both sides structural sheathing: chipboards $12 \mathrm{~mm}$ thick inside and $12.5 \mathrm{~mm}$ of special gypsum board externally applied to the structure. Nailing $\mathrm{N}$ 2.6/60 $\mathrm{mm}$ fasteners linking chip-boards and timber framing were spaced on distance $100 \mathrm{~mm}$ along the panel perimeter and staples K 1.6/50 mm were spaced on $80 \mathrm{~mm}$ along the gypsum board perimeter.

The first floor slab was constructed using solid wood joists with the cross-section of $60 \times 180 \mathrm{~mm}$ spaced on $450 \mathrm{~mm}$ and double joists $2 \times 60 \times 180 \mathrm{~mm}$ with

Table 1. Displacements and loading to the walls

\begin{tabular}{|c|c|c|c|c|c|c|c|c|c|c|c|c|c|}
\hline \multirow[b]{2}{*}{ No } & \multirow{2}{*}{$\begin{array}{l}\text { Total load to } \\
\text { building } \\
\text { P }[\mathrm{kN}]\end{array}$} & \multicolumn{12}{|c|}{ Displacements $\delta_{\mathrm{y}}$ and loading to the wall (points of displacements from Figure 4) } \\
\hline & & $\begin{array}{l}\text { wall } 3 \\
\mathrm{P}[\mathrm{kN}]\end{array}$ & $\begin{array}{c}\mathrm{J} 1 \\
{[\mathrm{~mm}]}\end{array}$ & $\begin{array}{l}\text { wall } 2 \\
\mathrm{P}[\mathrm{kN}]\end{array}$ & $\begin{array}{c}\mathrm{J} 2 \\
{[\mathrm{~mm}]}\end{array}$ & $\begin{array}{l}\text { wall } 1 \\
\mathrm{P}[\mathrm{kN}]\end{array}$ & $\begin{array}{c}\mathrm{J} 3 \\
{[\mathrm{~mm}]}\end{array}$ & $\begin{array}{l}\text { wall } 1 \\
\mathrm{P}[\mathrm{kN}]\end{array}$ & $\begin{array}{c}\mathrm{J} 4 \\
{[\mathrm{~mm}]}\end{array}$ & $\begin{array}{l}\text { wall } 2 \\
\mathrm{P}[\mathrm{kN}]\end{array}$ & $\begin{array}{c}\mathrm{J} 5 \\
{[\mathrm{~mm}]}\end{array}$ & $\begin{array}{l}\text { wall } 4 \\
\mathrm{P}[\mathrm{kN}]\end{array}$ & $\begin{array}{c}\mathrm{J} 6 \\
{[\mathrm{~mm}]}\end{array}$ \\
\hline 1 & 0 & 0.000 & 0.000 & 0.000 & 0.000 & 0.000 & 0.000 & 0.000 & 0.000 & 0.000 & 0.000 & 0.000 & 0.000 \\
\hline 2 & 4 & 1.100 & 0.067 & 0.987 & 0.010 & 0.650 & 0.000 & 0.650 & 0.010 & 0.987 & 0.010 & 1.264 & 0.010 \\
\hline 3 & 8 & 2.200 & 0.133 & 1.974 & 0.040 & 1.300 & 0.010 & 1.300 & 0.020 & 1.974 & 0.020 & 2.529 & 0.020 \\
\hline 4 & $\underline{12}$ & 3.300 & $\underline{0.200}$ & 2.962 & $\underline{0.070}$ & 1.950 & $\underline{0.020}$ & 1.950 & $\underline{0.030}$ & 2.962 & $\underline{0.040}$ & 3.793 & $\underline{\mathbf{0 . 0 3 0}}$ \\
\hline 5 & 16 & 4.401 & 0.267 & 3.949 & 0.100 & 2.600 & 0.035 & 2.600 & 0.050 & 3.949 & 0.070 & 5.058 & 0.050 \\
\hline 6 & 20 & 5.502 & 0.333 & 4.936 & 0.140 & 3.250 & 0.045 & 3.250 & 0.060 & 4.936 & 0.110 & 6.322 & 0.060 \\
\hline 7 & $\underline{24}$ & 6.603 & $\underline{0.402}$ & 5.923 & $\underline{0.180}$ & 3.800 & $\underline{0.060}$ & 3.800 & $\underline{0.070}$ & 5.923 & $\underline{0.130}$ & 7.586 & $\underline{0.070}$ \\
\hline 8 & 28 & 7.703 & 0.503 & 6.910 & 0.230 & 4.550 & 0.075 & 4.550 & 0.100 & 6.910 & 0.160 & 8.851 & 0.080 \\
\hline 9 & 32 & 8.803 & 0.635 & 7.898 & 0.310 & 5.200 & 0.115 & 5.200 & 0.130 & 7.898 & 0.190 & 10.115 & 0.090 \\
\hline 10 & 36 & 9.904 & 0.790 & 8.885 & 0.410 & 5.850 & 0.150 & 5.850 & 0.170 & 8.885 & 0.260 & 11.380 & 0.120 \\
\hline 11 & 40 & 11.004 & 0.933 & 9.872 & 0.510 & 6.500 & 0.190 & 6.500 & 0.210 & 9.872 & 0.330 & 12.641 & 0.160 \\
\hline
\end{tabular}


spacing $400 \mathrm{~mm}$ for the span of the floor diaphragm correspondingly 3.00 and $3.90 \mathrm{~m}$. Chip-boards thickness of $19 \mathrm{~mm}$ were used in construction of upper sheathing and $12.5 \mathrm{~mm}$ the gypsum boards were attached bottom to the joists as the finishes. Bolts $12 \mathrm{~mm}$ dia. spaced with distance $1000 \mathrm{~mm}$ along the floor joists support perimeter

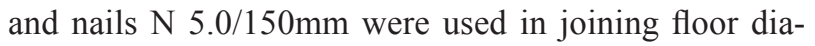
phragm with walls.

Timber rafters with the cross-section of $45 \times 180 \mathrm{~mm}$ spaced axially on $625 \mathrm{~mm}$, the top structural sheathing with $12 \mathrm{~mm}$ thickness chip-boards on the top and $12.5 \mathrm{~mm}$ thickness of the gypsum boards bottom were used in the roof structure.

\section{Program of the experimental test}

Horizontal loading in the form of two concentrated forces distributed sectional through the rigid steel beam was applied on the height of the first floor level (Malesza et al. 2004). Two steel ties, loading device and steel thrust structure assembled and firmly fixed to the RC floor slab over the basement were used in the test setup (see Fig. 4).

a)

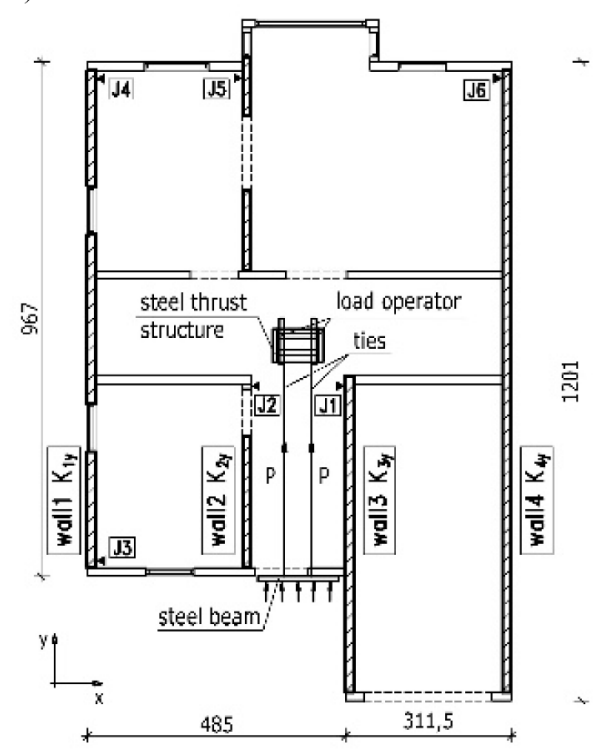

b)

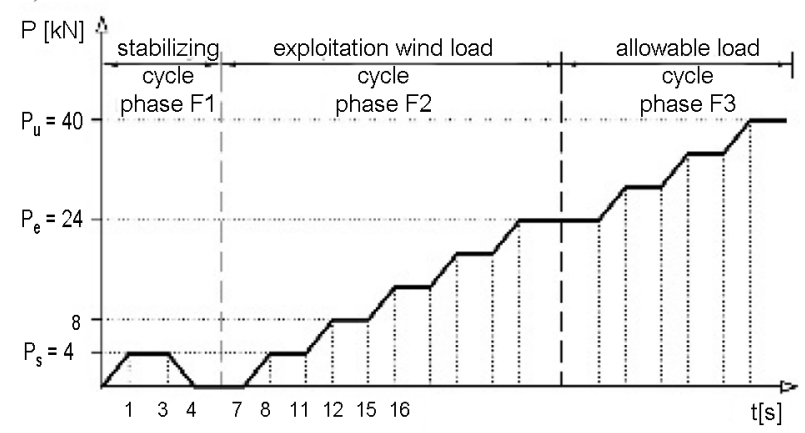

Fig. 4. Wall arrangement and loading operator: a) points of displacements reading during the test, b) diagram of loading application the building and phases of applied loading to the building structure
Location of displacement measurement points marked J1 - J6 is shown in Figure 5a with scheme of the loading application to structure presents.

The test was carried out and displacements were measured for the following stages of loading according to Figure $5 \mathrm{~b}$ :

- phase F1, stabilizing loading and displacements under lateral load $P_{s}=4.0 \mathrm{kN}$;

- phase F2, corresponding to exploitation wind load acting to the building $P_{e}=24.0 \mathrm{kN}$;

- phase F3, the final value of allowable load in respect of safety of the structural elements interconnecting links $P_{u}=40.0 \mathrm{kN}$.

a)

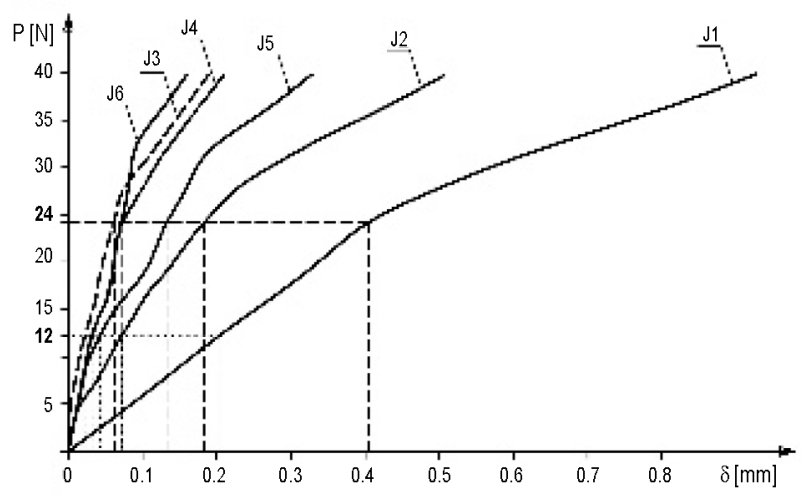

b)

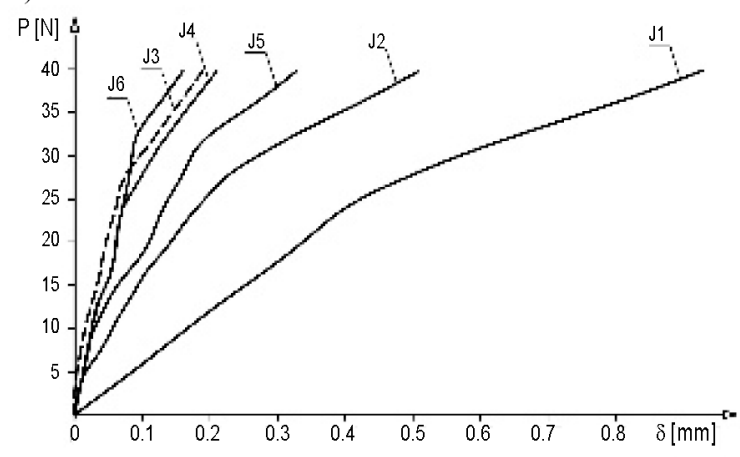

c)

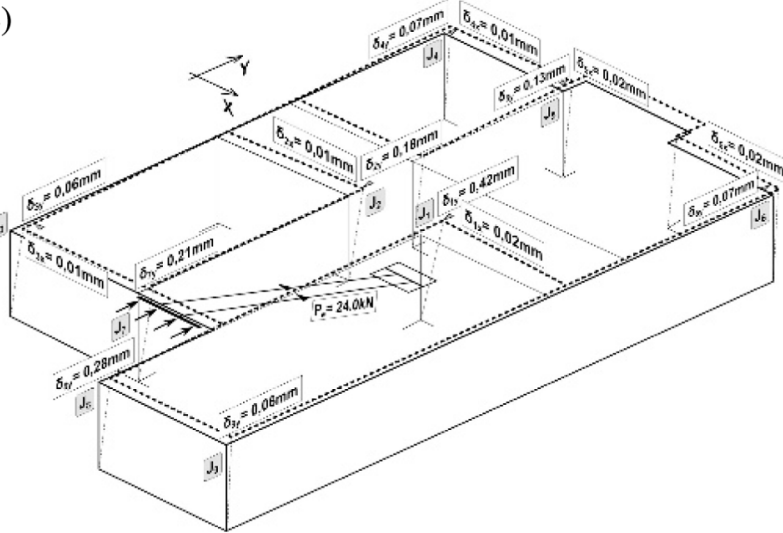

Fig. 5. Walls displacements under: a) different stages of loading applied to whole building structure, b) walls displacements in the function of sharing loadings, c) deformation in the plane of building under exploitation load $P_{e}=24.0 \mathrm{kN}$ and lateral torsion moment $M_{e}=14.19 \mathrm{kNm}$ 
The wall top edge displacements at the level of the bottom floor diaphragm were measured in two directions: perpendicular and parallel to the line of applied loading. Dial indicators of 0.001 the measuring accuracy and PELTRON PCx50 inductive gauges were used in displacements readings. Readings were realized for each $4.0 \mathrm{kN}$ applied loading increment.

\section{Results of experimental test}

Selected test results of the walls displacements in indicated direction of the applied loading are presented in Table 1. Displacements of the first floor diaphragm in marked points J1 to J6 in Figure 5a under lateral load of $12.0 \mathrm{kN}$ and consequently $24.0 \mathrm{kN}$ are underlined in Table 1 and then compared with results obtained from numerical analysis.

Figure 5a presents displacements of walls in marked points for different loading levels. Figure $5 \mathrm{~b}$ presents the displacements of the wall top edges in the function of sharing loading distributed in relation to these walls stiffness according to formula: $P_{i}=K_{i} \cdot \delta_{y i}$.

Analytical model representing behavior of the whole building structure has been built on the base of tests of wood used in the structure of tested building. Also connection of wood-to-wood based panel were tested and the fastener characteristics were evaluated due to adopt it in the numeric model of structure. Tests of the wall panels used in building structure were conducted due to obtain their stiffness and strength characteristics. It is worthy to underline the test of wall panels was conducted under combined lateral and vertical loads because these walls used in building structure are working as the load bearing and stiffening elements.

\section{Materials and connections characteristics used in analysis of building test result}

\subsection{Material characteristics}

The main objective of the test presented in Malesza and Miedzialowski (1999) was evaluation of load-slip characteristic and strength characteristic of mechanical fastener linking two timber elements for the purpose of analytical modeling the structure. Mechanical properties of wood and wood-based boards used in construction were investigated and selected results of tests of wood and woodbased boards characteristics are set in Table 2 .

Table 2. Material properties given from tests

\begin{tabular}{l|c|c|c|c|c}
\hline \multirow{2}{*}{ Material } & $\mathrm{E}_{11}$ & $\mathrm{E}_{22}$ & $\mathrm{G}$ & \multirow{2}{*}{$V_{12}$} & \multirow{2}{*}{$V_{21}$} \\
\cline { 2 - 4 }$[\mathrm{MPa}]$ & {$[\mathrm{MPa}]$} & {$[\mathrm{MPa}]$} & & \\
\hline Wood & 11500 & 530 & 585 & 0.3690 & 0.0341 \\
Plywood & 10900 & 8700 & 790 & 0.1740 & 0.0380 \\
Chipboard & 4500 & 3800 & 800 & 0.1640 & 0.2430 \\
$\begin{array}{l}\text { Gypsum } \\
\text { board }\end{array}$ & 3900 & 3500 & 1800 & 0.1062 & 0.1636 \\
\hline
\end{tabular}

\subsection{Load-displacements characteristic of fasteners}

Experimental load-slip characteristic tests of chipboard to framing connection were conducted according to procedure indicated in standard EN 26891 (ISO 6891):1991. The maximum expected lateral load on fastener has been evaluated from standard failure load of connection and corresponding equations referring to this mode. Typical mode of failure for minimum shear load and load displacements characteristic for different wood-base boards is presented in Figure 6.

Twenty samples of sheathing board-to-timber connections being done within process of wall panel construction were next tested where displacement were measured for the increment of loading. Maximum of lateral fastener loading were assumed from immediate test of connection. Considering nailing used in joint fastening sheathing to framing the maximum lateral load was $1.22 \mathrm{kN}$. The slip increments under single increment of loading were measured with accuracy $0.0016 \mathrm{~mm}$. The slip of joint obtained from mathematic function describes load-slip characteristic of connection, used in modeling of 3D wall and floor diaphragms.

a)

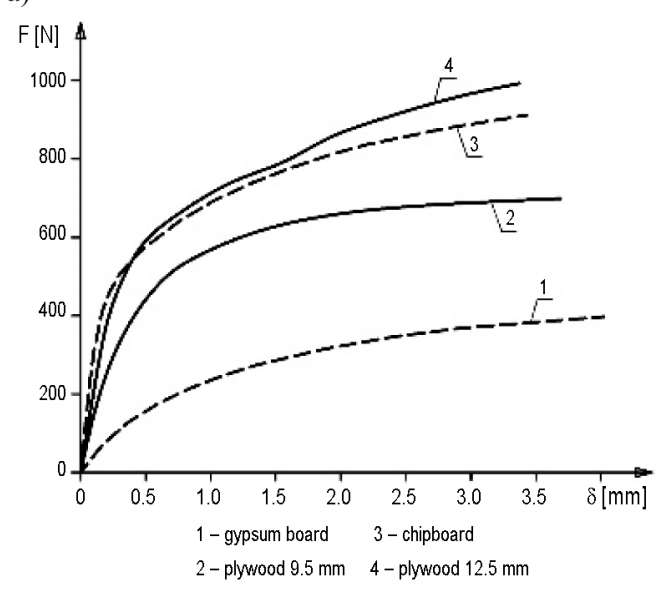

b)

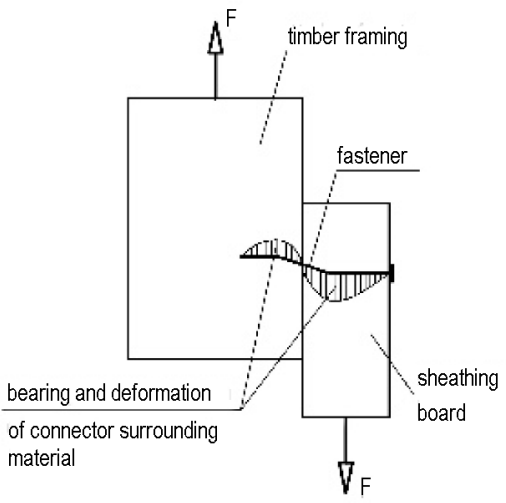

Fig. 6. The load- slip characteristics of fastener behavior: a) diagram of loading and failure mode of fastener, b) load-slip characteristics of sheathing to framing connectors for different wood-derivatives 
Mathematic function describing the load-slip characteristic of joint behavior has been adopted from Foschi (1974). This function was used in description of dowel bearing to the surrounding wood (Hunt, Bryant 1990). The function used in description of the fastener load-slip $F_{1}=f(\delta)$ characteristic has been applied in the form:

$$
F=(a+b \cdot \delta) \cdot\left[1-\exp \left(-\frac{c}{a} \cdot \delta\right)\right]
$$

This formula was adopted in numerical modeling of the wood-framed wall and floor diaphragms and parameters $a, b, c$ were evaluated applying statistic program and for experimentally tested chipboard to framing joints were in value:

$$
a=599.75 ; b=100.91 ; c=2498.93 .
$$

The best fitted curve describing fastener behaviour depending on sheathing material has been selected for $a, b$ and $c$ parameters, where these parameters were obtained from results of tests for different sheathing material used in construction. Also the formulae describing the load-slip characteristic were used in numerical modelling of varying walls construction in Poland.

The immediate tests and load-slip curves were done according to requirements of EN 26891:1991, ISO 6891:1983 in order to define the basic deformability characteristic $F=f(\delta)$ and strength of mechanically fastened boards-to-timber connections with dowel type of fastener.

\section{Adopted models and analytical study}

Analytic models are built applying finite element method using procedure in Malesza and Miedzialowski (2003, 2006). Equilibrium equations for considered schemes including nonlinearity have the form:

$$
\boldsymbol{K}(q) \boldsymbol{q}=\boldsymbol{P},
$$

where $\boldsymbol{K}$ and $\boldsymbol{P}$ are the global stiffness and loading matrixes obtained from formulae:

$$
\begin{gathered}
\boldsymbol{K}=\sum_{s} \sum_{r e} \sum_{e} \boldsymbol{K}_{e} ; \\
\boldsymbol{P}=\sum_{s} \sum_{r e} \sum_{e}\left(\boldsymbol{P}_{h}+\boldsymbol{P}_{w}\right) ;
\end{gathered}
$$

$\boldsymbol{K}_{e}-$ stiffness matrix of individual composing considered schemes elements:

$$
\boldsymbol{K}_{e}=\int_{\dot{U}} \boldsymbol{B}^{T} \boldsymbol{D} \boldsymbol{B} d \grave{U} ;
$$

$\boldsymbol{D}$ - constitutive matrix; $\boldsymbol{B}$ - strain matrix; $\boldsymbol{P}_{h}, \boldsymbol{P}_{w}-$ adequate horizontal and vertical loadings; $s$-walls, floors and other elements composing structure; re - types of elements in structure: posts, joists, fasteners, sheathing; $e-$ sequent elements of each type.
Displacements vectors of beam elements are described in the form:

$q_{b}=\left\{u_{1}, v_{1}, w_{1}, \varphi_{x 1}, \varphi_{y 1}, \varphi_{z 1}, u_{2}, v_{2}, w_{2}, \varphi_{x 2}, \varphi_{y 2}, \varphi_{z 2}\right\}$

and four-nodes shell are given in the form:

$q_{p}=\left\{u_{1}, v_{1}, w_{1}, \varphi_{x 1}, \varphi_{y 1}, \varphi_{z 1}, \ldots, u_{4}, v_{4}, w_{4}, \varphi_{x 4}, \varphi_{y 4}, \varphi_{z 4}\right\}$.

Analysis of displacements and redistribution of external lateral load to each wall were conducted assuming experimentally obtained characteristics $P=f(\delta)$ of wall diaphragms reflecting deformable supporting system received from experimental tests of different form and geometry wood-framed wall panels (Malesza, Miedzialowski 2006; Malesza et al. 2004).

Distribution of external loading to the supporting wall system was assumed for different static schemes. External horizontal loading was imposed in static schemes in adequate points to structure within tests process. Distribution of loadings to the walls was developed through redistribution of these loadings in adequate static scheme (1D, 2D, 3D).

Analytic engineering models (1D, 2D) to more complex 3D models were used in analytic investigations and different approximations of theoretic results of analysis were obtained comparing to the experimental tests results.

Character of horizontal loadings was taken on the base of Standard wind assumptions. In the specified regions of structure like elements connections, edge and corners of building, the analytic 3D model allows to calculate appearing internal forces and stressing.

The continuous beam analogy in longitudinal direction of building are presented in Figure 7a supported on deformable walls. In similar way distribution of external loading were computed in the transverse direction of building, where the rigid beam is loaded with torsion moment resulting from external loading and its eccentricity relating to the wall plane gravity center.

The stiffness $K_{i}=P / \delta$ of walls computed for the phase of exploitation loading resulted from wind load were taken correspondingly in value of: $K_{1 y}=24610 \frac{\mathrm{kN}}{\mathrm{m}}$; $K_{2 y}=13901 \frac{\mathrm{kN}}{\mathrm{m}} ; K_{3 y}=15522 \frac{\mathrm{kN}}{\mathrm{m}} ; K_{4 y}=30764 \mathrm{kN} / \mathrm{m}$. The stiffness values were obtained from analysis of floor slab as a rigid beam and its reaction on the supports for limited lateral displacements of the wall $1 / 300 \mathrm{~h}$. Computed deformations as a result of deformable wall displacements corresponding to the loading $P=12.0 \mathrm{kN}$ are respectively in values: $y_{1}=0.3412 \mathrm{~mm} ; y_{2}=0.6399 \mathrm{~mm}$; $y_{3}=0.6235 \mathrm{~mm} ; y_{4}=0.1490 \mathrm{~mm}$, while under loading $P=24 \mathrm{kN}$ displacements are: $y_{1}=0.5686 \mathrm{~mm}$; $y_{2}=1.0665 \mathrm{~mm} ; y_{3}=1.1383 \mathrm{~mm} ; y_{4}=0.2149 \mathrm{~mm}$. 
a)

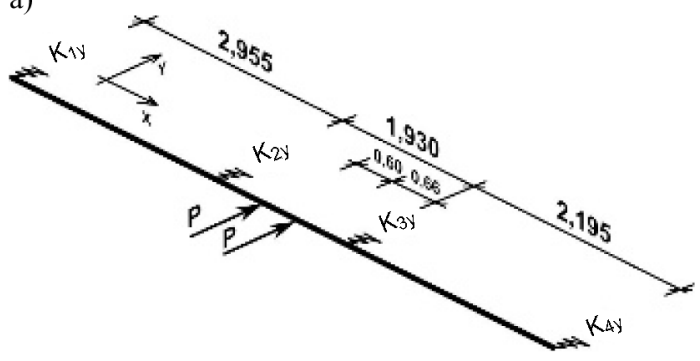

b)

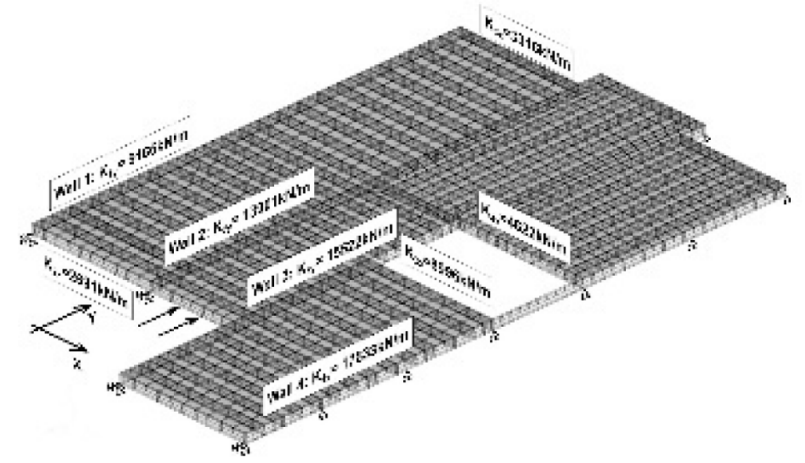

c)

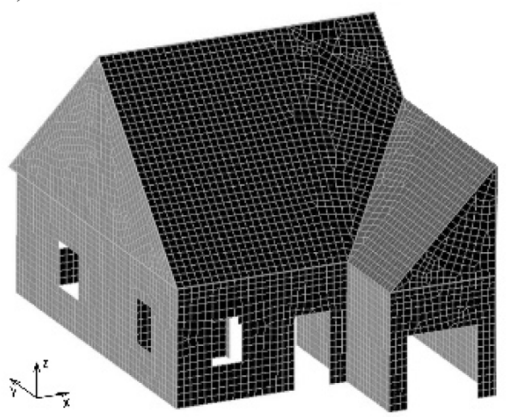

Fig. 7. Modelling of structure adopted in the work: a) analogy of continuous beam on deformable walls, b) the orthotropic plate on deformable walls, c) shell modelled whole building structure

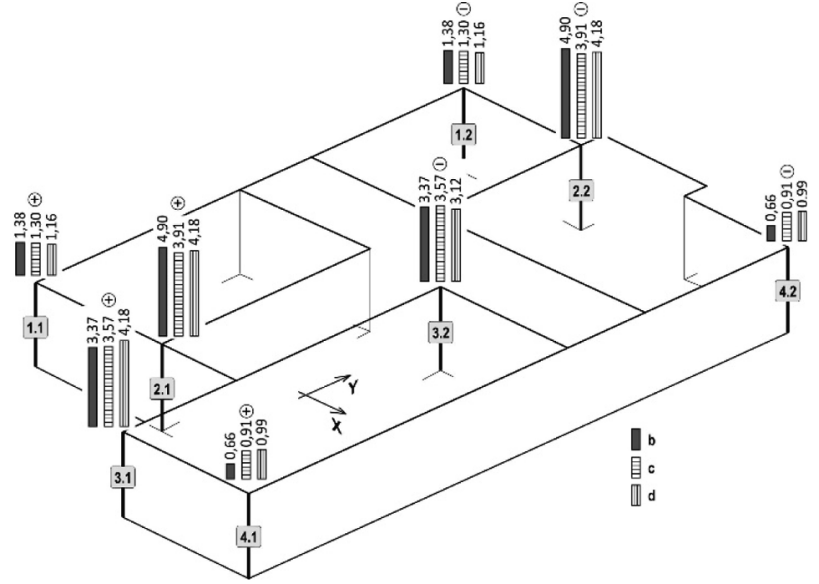

Fig. 9. Values of axial force in timber posts of walls for different models of analysis

\section{Comparative analysis}

Experimentally obtained results of displacements were compared to those analytically computed from rigid continuous beam analogy and obtained from orthotropic plate on deformable wall system. All displacements of the top edge of walls cannot exceed the limit value given in DIN 1052:2008-12. The allowable displacements for the wood-framed buildings constructed of the large panel wall system are limited to the value of $y_{\text {lim }}=0.002 \cdot h_{s}$ and in case of wall height of $h_{s}=2.74 \mathrm{~m}$ they cannot exceed value of $y_{\text {lim }}=5.48 \mathrm{~mm}$. This indicates adequately big reserve of the load bearing capacity of structure. Executed later on all non-structural elements in the form of internal finishes increases this reserve. The influence of internal finishes on final displacements and load bearing capacity can be also evaluated adopting authors analytic 3D model.

Displacements obtained in result of experimental test under lateral load $P=24.0 \mathrm{kN}$ are compared to analytically computed results from the continuous beam analogy and from numerical method for orthotropic plate and for 3D upper structure on deformable supporting walls and shown in Figure 8.

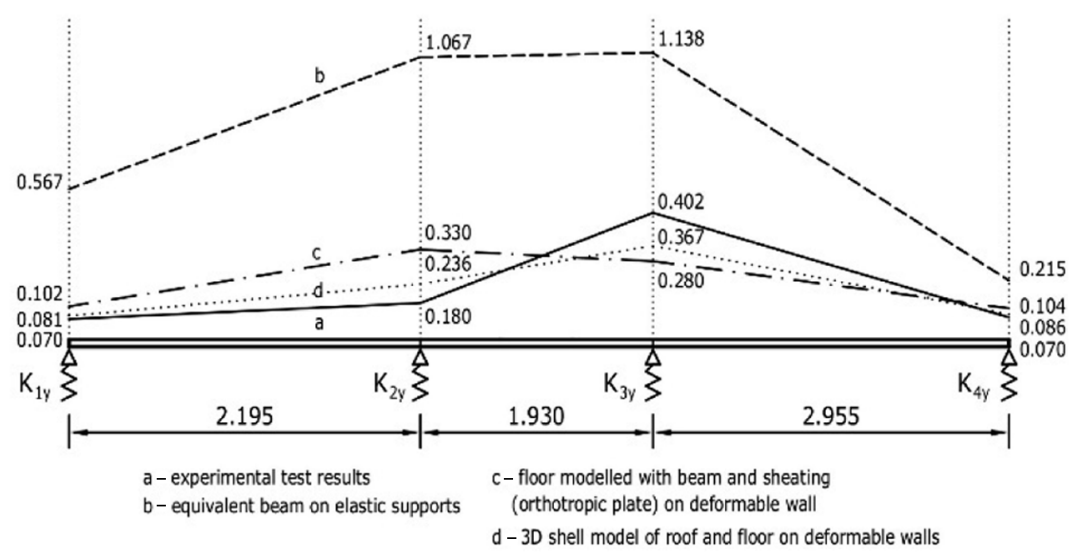

Fig. 8. Compared deformations obtained from varying models 
Internal axial forces in selected points under lateral test load applied to building $2 \times P=24.0 \mathrm{kN}$ in the walls posts for different analyzed models are presented in Figure 9.

\section{Conclusions}

The following conclusions are formulated on the basis of experimental test, analytical and numerical approach:

- Displacements on the height of floor above the ground level measured during the experimental test are much lower than limited values.

- Results of experimental test leads to conclusion that the wood-framed floor structure cannot be considered as infinitely rigid in its plane and building deformations in the plane confirms deformability and ability to displacements of floor diaphragm.

- Adopting the continuous beam analogy on deformable supporting walls displacements are 1.84 to 4.92 times higher than obtained from experiment, while the numerical method and orthotropic plate on deformable supports gives the displacements higher 1.45 to 2.54 times comparing to experiment under comparable level of loading.

- The displacements computed from 3D numerical model were $10-20 \%$ higher than from experiment.

- Experimentally obtained lower displacements than those from analytical analysis are resulted from higher stiffness of wall system due to diaphragms interconnections, their common interaction and threedimensional character of building structure.

- Also partial displacement has been accumulated on deformable connections between floor and wall diaphragms and in vertical joints between walls.

- In case of 3D model adopted in analysis higher deformations than from experiment comes from the stiffness of supporting walls.

- The three-dimensional model of the whole building structure including links interconnecting large walls and floors panels seems to be projecting and specifying the real displacements, load distribution among the wall system and corresponding stressing in interconnecting links.

- Axial forces in walls timber posts are differing 6-25\% for different models while 3D model shows the lowest values of internal forces in the cross-sections. Model 3D shows the most uniform distribution of axial internal forces in the walls posts.

- Disability in realization reported in the paper task came from limited sources and possibilities in developing and application of horizontal load. Building is owned by private investor and investigation process could not demonstrate evident signs of exceed the SLS and ULS. Place of horizontal force application has been selected as one of the only point in the structure where the simply constructed device allowed for investigation of effects influencing horizontal load on stressing and response of walls and floor in building as well as this afforded of building in natural scale.

\section{References}

DIN 1052:2008-12 Design of timber structures - General rules and rules for buildings. German standard.

Doudak, G.; McClure, G.; Smith, I. 2012. Experimental evaluation of load paths in light-frame wood structure, Journal of Structural Engineering 138(2): 258-265. https://doi.org/10.1061/(ASCE)ST.1943-541X.0000439

EN 1995 Design of timber structures. European standard.

EN 1990:2002 Eurocode - Basis of structural design. European standard.

EN 26891:1991, ISO 6891:1983 Timber structures. Joints made with mechanical fasteners. General principles for the determination of strength and deformation characteristics. European standard.

Filiatrault, A.; Christovasilis, I.; Wanitkorkul, A.; Van de Lindt, J. 2010. Experimental seismic response of a full-scale light-frame wood building, Journal of Structural Engineering 136(3): 246-254. https://doi.org/10.1061/(ASCE) ST.1943-541X.0000112

Foschi, R. O. 1974. Load slip characteristic of nails, Wood Science 7(1): 69-76.

Graham, D.; Carradine, D.; Bender, D.; Dolan, J. 2010. Performance of $\log$ shear walls subjected to monotonic and reverse-cyclic loading, Journal of Structural Engineering 136(1): 37-45. https://doi.org/10.1061/(ASCE)ST.1943$541 X .0000035$

Hite, M. C.; Shenton, III. H. 2002. Modeling of the non-linear behavior of wood frame shear walls, in $15^{\text {th }}$ ASCE Engineering Mechanics Conference, 2-5 June 2002, Columbia University.

Hong, J.; Barrett, D. 2010. Three-dimensional finite-element modeling of nailed connections in wood, Journal of Structural Engineering 136(6): 715-722.

https://doi.org/10.1061/(ASCE)ST.1943-541X.0000160

Hong, J.; Ni, C.; Vinson, M. 2012. Mid-ply truss wall system: High-performance shear wall for midrise wood-frame buildings, Journal of Structural Engineering 138(9): 1120 1127. https://doi.org/10.1061/(ASCE)ST.1943-541X.0000536

Hunt, E.; Bryant, A. M. 1990. Laterally loaded nail joints in wood, Journal of Structural Engineering 116(1). https://doi.org/10.1061/(ASCE)0733-9445(1990)116:1(111)

Kasal, B.; Leichti, R. J. 1994. Nonlinear finite element model of light-frame wood structures, Journal of Structural Engineering 120(12). https://doi.org/10.1061/(asce)0733-9445(1994)120:1(100)

Kasal, B.; Collins, M. S.; Paeverte, P.; Foliente, G. C. 2004. Design models of light frame wood buildings under lateral load, Journal of Structural Engineering 130(8).

https://doi.org/10.1061/(ASCE)0733-9445(2004)130:8(1263)

Kassem, W.; Elsheikh, A. 2010. Estimation of shear strength of structural shear walls, Journal of Structural Engineering 136(10): 1215-1224. https://doi.org/10.1061/(ASCE)ST.1943-541X.0000218

Li, M.; Foschi, R.; Lam, F. 2012. Modeling hysteretic behavior of wood shear walls with a protocol-independent nail connection algorithm, Journal of Structural Engineering 138(1): 99-108. https://doi.org/10.1061/(ASCE)ST.1943-541X.0000438

Liang, H.; Wen, Y.; Foliente, G. 2011. Damage modeling and damage limit state criterion for wood-frame buildings subjected to seismic loads, Journal of Structural Engineering 137(1): 41-48. https://doi.org/10.1061/(ASCE)ST.1943-541X.0000272 
Malesza, M.; Miedzialowski, C. 1999. Experimental test of wood-framed buildings wall, Building and Engineering 4 (in Polish).

Malesza, M.; Miedzialowski, C. 2003. Discrete analytical models of wood-framed with sheathing buildings structures and selected experimental test results, Archives of Civil Engineering 49(2): 213-240.

Malesza, M.; Miedzialowski, C. 2006. The wood-framed with sheathing buildings - alternative for housing construction, Journal of Civil Engineering and Management 12(2): 143-151.

Malesza, M.; Miedzialowski, C.; Malesza, J. 2004. Experimental and analytical deformations of the wood-framed building under lateral load, in The $8^{\text {th }}$ World Conference on Timber Engineering (WCTE), 14-17 June 2004, Lahti, Finland.

Malesza, M.; Miedzialowski, C.; Malesza, J. 2013. New approach in construction of the wood-framed residential buildings, in The frame of modern materials, installations and construction technologies. Biala-Podlaska, 124-136.

Ni, C.; He, M.; Chen, S. 2012. Evaluation of racking performance of wood portal frames with different wall configurations and construction details, Journal of Structural Engineering 138(8): 984-994. https://doi.org/10.1061/(ASCE)ST.1943-541X.0000537

Pang, W.; Rosowsky, D.; Pei, S.; van de Lindt, J. 2010. Simplified direct displacement design of six-story woodframe building and pretest seismic performance assessment, Journal of Structural Engineering 136(7): 813-825. https://doi.org/10.1061/(ASCE)ST.1943-541X.0000181

Pang, W.; Shirazi, S. M. H. 2013. Corotational model for cyclic analysis of light-frame wood shear walls and diaphragms, Journal of Structural Engineering 139(8): 1303-1317. https://doi.org/10.1061/(ASCE)ST.1943-541X.0000595

Pei, S.; van de Lindt, J.; Wehbe N.; Liu, H. 2013. Experimental study of collapse limits for wood frame shear walls, Journal of Structural Engineering 139(9): 1489-1497. https://doi.org/10.1061/(ASCE)ST.1943-541X.0000730

Philips, T. L.; Itani, R. Y.; McLean, D. L. 1993. Lateral load sharing by diaphragms in wood-framed buildings, Journal of Structural Engineering 119(5). https://doi.org/10.1061/ (ASCE)0733-9445(1993)119:5(1556)

PN-EN 1995-1-1 Design of timber structures. Polish standard.

Robertson, A.; Griffiths, R. 1981. Factors affecting the racking resistance of timber frame panels, Journal of the Institution of Structural Engineering 59B(4): 49-63.
Schmidt, R. J.; Moody, R. C. 1989. Modeling laterally loaded light-frame buildings, Journal of Structural Engineering 115(1): 201-217. https://doi.org/10.1061/(ASCE)07339445(1989)115:1(201)

Songlai, C.; Chengmou, F.; Jinglong, P. 2010. Experimental study on full-scale light frame wood house under lateral load, Journal of Structural Engineering 136(7): 805-812. https://doi.org/10.1061/(ASCE)ST.1943-541X.0000178

Tissel, J. R. 1993. Wood structural panel shear walls. Research Report No. 154, Revised May 1993. American Plywood Association.

Tissel, J. R.; Elliott, J. R. 1999. Plywood diaphragms. Research Report No. 138, September. American Plywood Association.

Van de Lindt, J.; Pei, S.; Liu, H.; Filiatrault, A. 2010a. Threedimensional seismic response of a full-scale light-frame wood building: Numerical study, Journal of Structural Engineering 136(1): 56-65.

https://doi.org/10.1061/(ASCE)ST.1943-541X.0000086

Van de Lindt, J.; Pei, S.; Pryor, S.; Shimizu, H.; Isoda, H. 2010b. Experimental seismic response of a full-scale sixstory light-frame wood building, Journal of Structural Engineering 136(10): 1262-1272.

https://doi.org/10.1061/(ASCE)ST.1943-541X.0000222

Van de Lindt, J.; Pei, S.; Pang, W.; Shirazi, S. 2012. Collapse testing and analysis of a light-frame wood garage wall, Journal of Structural Engineering 138(4): 492-501. https://doi.org/10.1061/(ASCE)ST.1943-541X.0000472

Van de Lindt, J.; Rosowsky, D.; Pang, W.; Pei, S. 2013. Performance-based seismic design of midrise woodframe buildings, Journal of Structural Engineering 139(8): 1294-1302. https://doi.org/10.1061/(ASCE)ST.1943$541 X .0000653$

Wang, W.; Eamon, C. 2013. Load path uncertainty in a wood structure and the effect on structural reliability, Engineering Structures 56: 889-896. https://doi.org/10.1016/j.engstruct.2013.06.006

Wang, Y.; Rosowsky, D.; Pang, W. 2010. Performance-based procedure for direct displacement design of engineered wood-frame structures, Journal of Structural Engineering 136(8): 978-988. https://doi.org/10.1061/(ASCE)ST.1943$541 X .0000188$

Winkel, M.; Smith, I. 2010. Structural behavior of wood lightframe wall segments subjected to in-plane and out-ofplane forces, Journal of Structural Engineering 136(7): 826-836. https://doi.org/10.1061/(ASCE)ST.1943$541 X .0000170$

Czeslaw MIEDZIALOWSKI. Prof. The Head of the Structural Mechanics Chair at the Faculty of Civil and Environment Engineering in Bialystok University of Technology. Professor of structural mechanics. Published over 150 scientific papers. Research interests: implementation of numerical methods in the structural mechanics, interaction of soil - building structures, durability of structures in historical buildings.

Jaroslaw MALESZA. PhD in Bialystok University of Technology - Faculty of Civil and Environment Engineering (2005). Research interests: structural analyses and investigations of the reinforced concrete, stiffness, stability and load bearing capacity of timber structure in civil engineering.

Leonas USTINOVICHIUS. Dr Habil Prof, Chairman of the Laboratory of Intelligent Building Technology and Management Research Laboratory at Vilnius Gediminas Technical University. Doctor (1989), Doctor Habil (2004). Published more than 150 scientific papers. Research interests: building technology and management, decision-making theory, automation in design, expert systems. 